Prepared in cooperation with the Idaho Department of Water Resources and Idaho Power Company

\title{
Groundwater-Quality Data from the Eastern Snake River Plain Aquifer, Jerome and Gooding Counties, South-Central Idaho, 2017
}

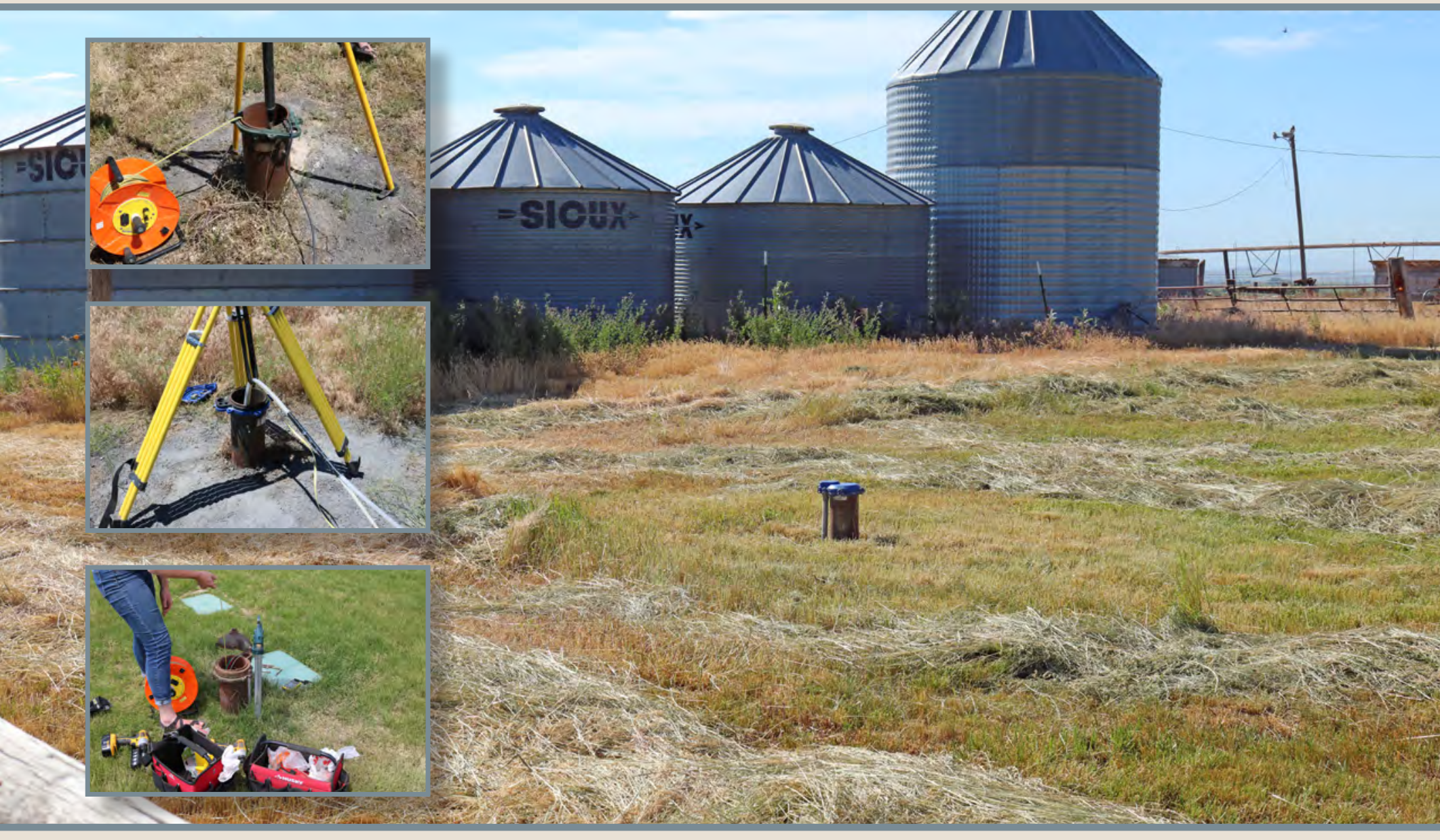

Data Series 1085 


\section{Cover:}

Background: Domestic well in an alfalfa field in the Jerome/Gooding County groundwater-quality area, south-central Idaho.

Top: Well with a groundwater level tape in well and the tip of a survey rod used to survey location and elevation in the Jerome/Gooding County groundwater-quality area, south-central Idaho.

Middle: Water-quality sampling line held down with a tripod in a well in the Jerome/ Gooding County groundwater-quality area, south-central Idaho.

Bottom: U.S. Geological Survey Hydrologist measuring the groundwater level of well in the Jerome/Gooding County groundwater-quality area, south-central Idaho.

All photographs by Kenneth D. Skinner, U.S. Geological Survey, June 2017. 


\section{Groundwater-Quality Data from the Eastern Snake River Plain Aquifer, Jerome and Gooding Counties, South-Central Idaho, 2017}

By Kenneth D. Skinner

Prepared in cooperation with the Idaho Department of Water Resources and Idaho Power Company

Data Series 1085 


\title{
U.S. Department of the Interior RYAN K. ZINKE, Secretary
}

\section{U.S. Geological Survey William H. Werkheiser, Deputy Director exercising the authority of the Director}

\author{
U.S. Geological Survey, Reston, Virginia: 2018
}

For an overview of USGS information products, including maps, imagery, and publications, visit https://store.usgs.gov/.

For more information on the USGS — the Federal source for science about the Earth, its natural and living resources, natural hazards, and the environment-visit https://www.usgs.gov/ or call 1-888-ASK-USGS (1-888-275-8747).

Any use of trade, firm, or product names is for descriptive purposes only and does not imply endorsement by the U.S. Government.

Although this information product, for the most part, is in the public domain, it also may contain copyrighted materials as noted in the text. Permission to reproduce copyrighted items must be secured from the copyright owner.

Suggested citation:

Skinner, K.D., 2018, Groundwater-quality data from the eastern Snake River Plain aquifer, Jerome and Gooding Counties, south-central Idaho, 2017: U.S. Geological Survey Data Series 1085, 20 p., https://doi.org/10.3133/ds1085.

ISSN 2327-638X (online) 


\section{Contents}

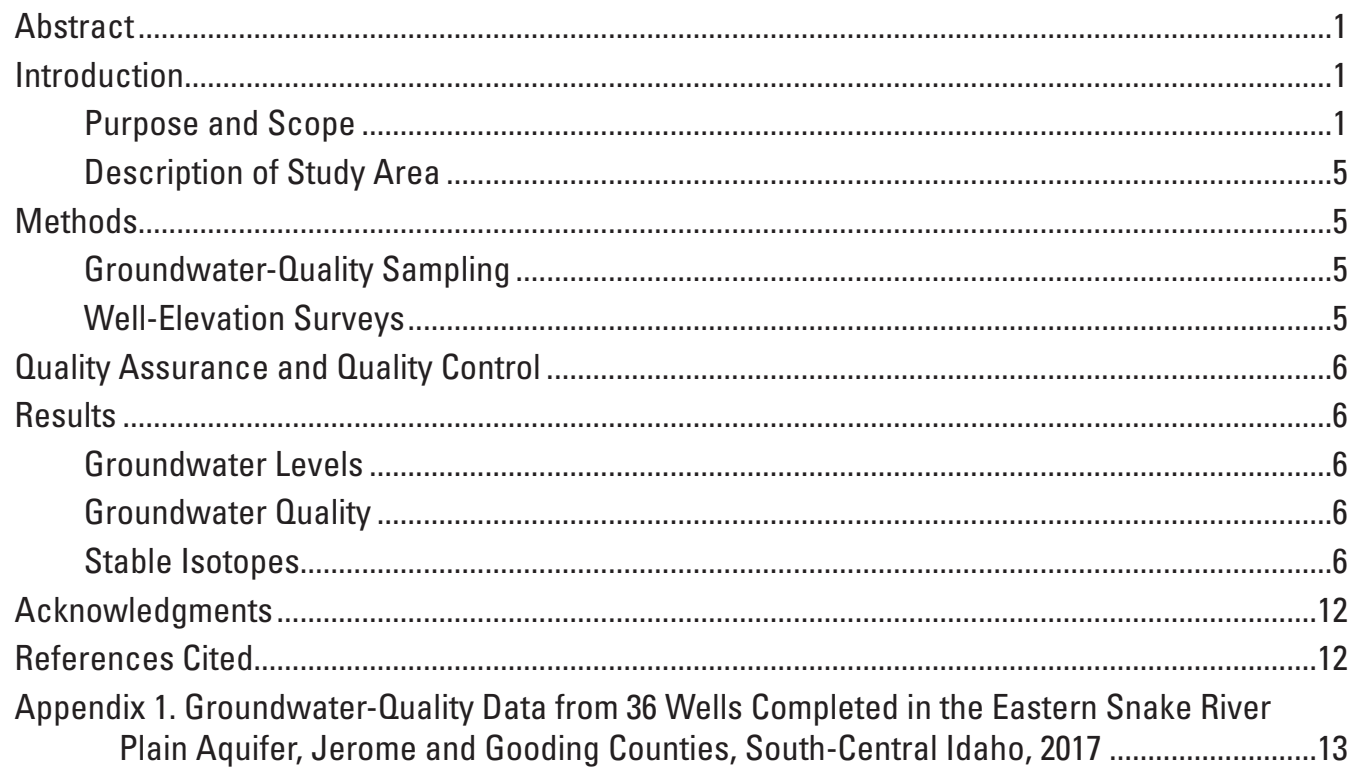

\section{Figures}

1. Map showing groundwater-quality sampling locations and site identification numbers in Jerome and Gooding Counties, south-central Idaho......................................2

2. Map showing measured groundwater-level altitudes at 36 wells, Jerome and Gooding Counties, south-central Idaho

3. Map showing specific conductance measured from groundwater in 36 wells in Jerome and Gooding Counties, south-central Idaho

4. Map showing nitrate $\left(\mathrm{NO}_{2}+\mathrm{NO}_{3}\right.$ as $\left.\mathrm{N}\right)$ from groundwater-quality samples in 36 wells in Jerome and Gooding Counties, south-central Idaho.

5. Map showing relative oxygen stable isotope ratios $\left(\delta^{18} 0\right)$ from groundwater quality samples in 36 wells in Jerome and Gooding Counties, south-central Idaho.......10

6. Graph showing stable isotope relative ratios of hydrogen and oxygen from groundwater quality samples in 36 wells in Jerome and Gooding Counties, south-central Idaho

\section{Tables}

1. Groundwater-quality sampling wells, coordinates, and type in Jerome and Gooding Counties, south-central, Idaho

2. Groundwater-quality parameters sampled from 36 wells completed in the Eastern Snake River Plain aquifer, Jerome and Gooding Counties, south-central Idaho, 2017.....4 


\section{Conversion Factors}

U.S. customary units to International System of Units

\begin{tabular}{|c|c|c|}
\hline Multiply & By & To obtain \\
\hline \multicolumn{3}{|c|}{ Length } \\
\hline inch (in.) & 2.54 & centimeter $(\mathrm{cm})$ \\
\hline inch (in.) & 25.4 & millimeter $(\mathrm{mm})$ \\
\hline foot (ft) & 0.3048 & meter $(\mathrm{m})$ \\
\hline \multicolumn{3}{|c|}{ Flow rate } \\
\hline gallon per minute (gal/min) & 0.06309 & liter per second $(\mathrm{L} / \mathrm{s})$ \\
\hline \multicolumn{3}{|c|}{ Transmissivity } \\
\hline foot squared per day $\left(\mathrm{ft}^{2} / \mathrm{d}\right)$ & 0.09290 & meter squared per day $\left(\mathrm{m}^{2} / \mathrm{d}\right)$ \\
\hline
\end{tabular}

Temperature in degrees Celsius $\left({ }^{\circ} \mathrm{C}\right)$ may be converted to degrees Fahrenheit $\left({ }^{\circ} \mathrm{F}\right)$ as follows:

$$
{ }^{\circ} \mathrm{F}=\left(1.8 \times{ }^{\circ} \mathrm{C}\right)+32 .
$$

\section{Datums}

Vertical coordinate information is referenced to the North American Vertical Datum of 1988 (NAVD 88).

Horizontal coordinate information is referenced to the North American Datum of 1983 (NAD 83) [2011].

Altitude, as used in this report, refers to distance above the vertical datum.

\section{Supplemental Information}

Specific conductance is given in microsiemens per centimeter at 25 degrees Celsius $(\mu \mathrm{S} / \mathrm{cm}$ at $\left.25^{\circ} \mathrm{C}\right)$.

Concentrations of chemical constituents in water are given in either milligrams per liter (mg/L) or micrograms per liter $(\mu \mathrm{g} / \mathrm{L})$. 


\title{
Groundwater-Quality Data from the Eastern Snake River Plain Aquifer, Jerome and Gooding Counties, South-Central Idaho, 2017
}

\author{
By Kenneth D. Skinner
}

\begin{abstract}
Groundwater-quality samples and water-level data were collected from 36 wells in the Jerome/Gooding County area of the eastern Snake River Plain aquifer during June 2017. The wells included 30 wells sampled for the U.S. Geological Survey's National Water-Quality Assessment project, plus an additional 6 wells were selected to increase spatial distribution. The data provide water managers with the ability for an improved understanding of groundwater quality and flow directions in the area. Groundwater-quality samples were analyzed for nutrients, major ions, trace elements, and stable isotopes of water. Quality-assurance and quality-control measures consisted of multiple blank samples and a sequential replicate sample. All data are available online at the USGS National Water Information System.
\end{abstract}

\section{Introduction}

In 2017, the last scheduled groundwater-quality sampling of the Jerome/Gooding well network was conducted for the U.S. Geological Survey National Water-Quality Assessment project (USGS NAWQA). The USGS NAWQA project provides nationally consistent information on the quality of the Nation's streams and groundwater, changes in water quality over time, and natural features and human activities affecting the quality of surface water and groundwater. The sampling of 30 wells in the Jerome/Gooding County area supports these project goals at local, regional, and national scales. Data from this study will be used to study regional trends of groundwater quality and to characterize groundwater quality with respect to depth and hydrologic position in the aquifer (Rowe and others, 2013).

This study was done in cooperation with Idaho Department of Water Resources (IDWR) and Idaho Power Company, which share an interest in groundwater quality and quantity in the region. The sampling effort along with additional data to improve spatial distribution and groundwater-quality constituents will aid ongoing water management activities as well as monitoring of groundwater and spring discharge from the eastern Snake River Plain (ESRP) aquifer. The data may also be useful in establishing monitoring locations for various management activities.

\section{Purpose and Scope}

This report documents the results of groundwater-quality and water-level data for 30 NAWQA wells and 6 additional wells in June 2017. These data will assist with evaluating groundwater-level and water-quality trends. The six additional wells sampled in this study were selected to fill data gaps and expand the spatial resolution of the NAWQA well network (fig. 1, table 1). The sampling of these six wells complements NAWQA sampling of 30 wells in the area by using the same protocols and sampling laboratory schedules (table 2). Groundwater-quality samples were analyzed for nutrients, major ions, trace elements, and stable isotope samples were collected at all 36 wells (table 2). 

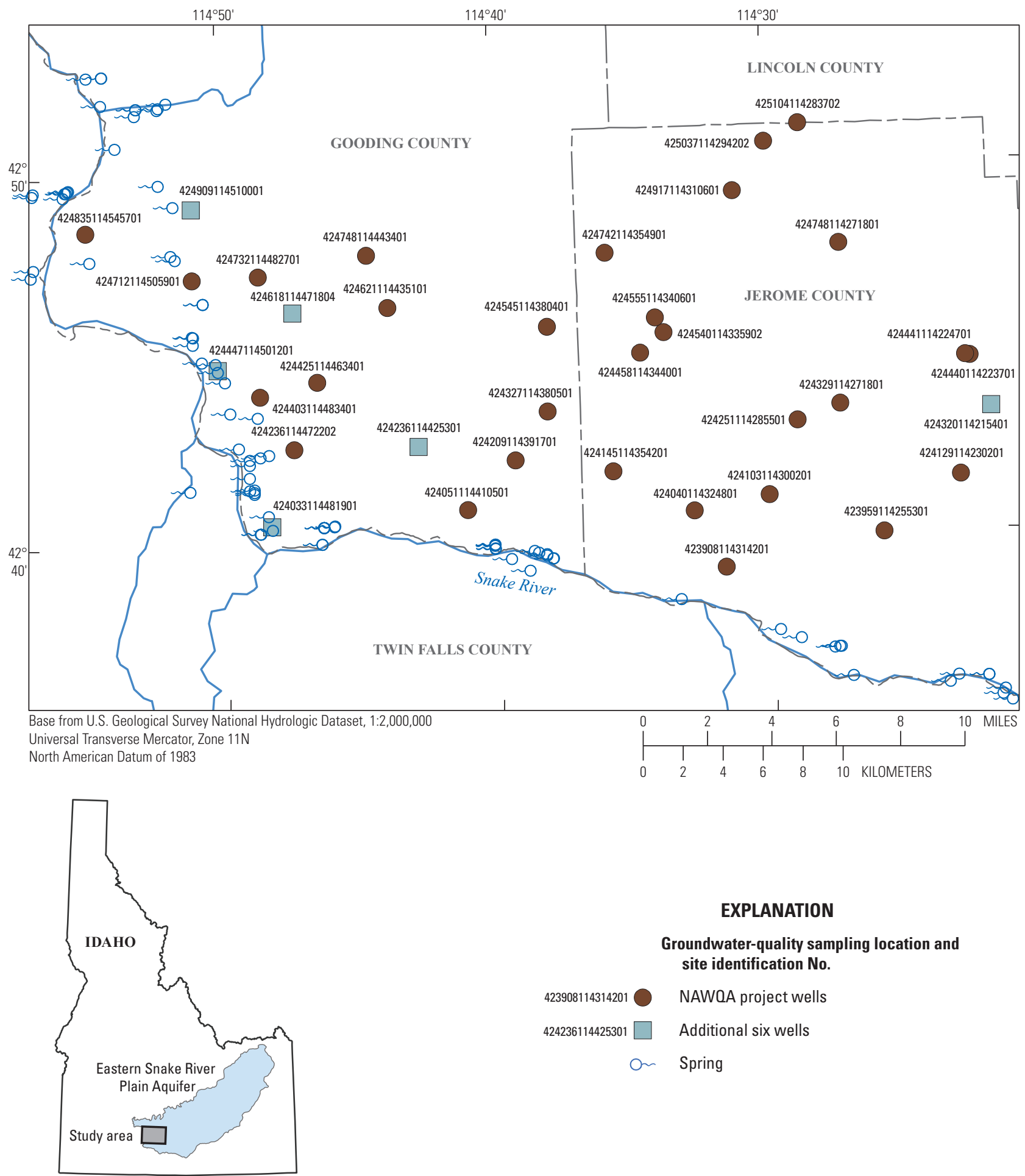

\section{EXPLANATION}

Groundwater-quality sampling location and site identification No.

$423908114314201 \bigcirc$ NAWQA project wells

$424236114425301 \square \quad$ Additional six wells

On Spring

Figure 1. Groundwater-quality sampling locations and site identification numbers in Jerome and Gooding Counties, south-central Idaho. 
Table 1. Groundwater-quality sampling wells, coordinates, and type in Jerome and Gooding Counties, south-central, Idaho.

[Groundwater-quality sampling locations and site identification Nos. are shown in figure 1. Well type: NAWQA, National Water-Quality Assessment]

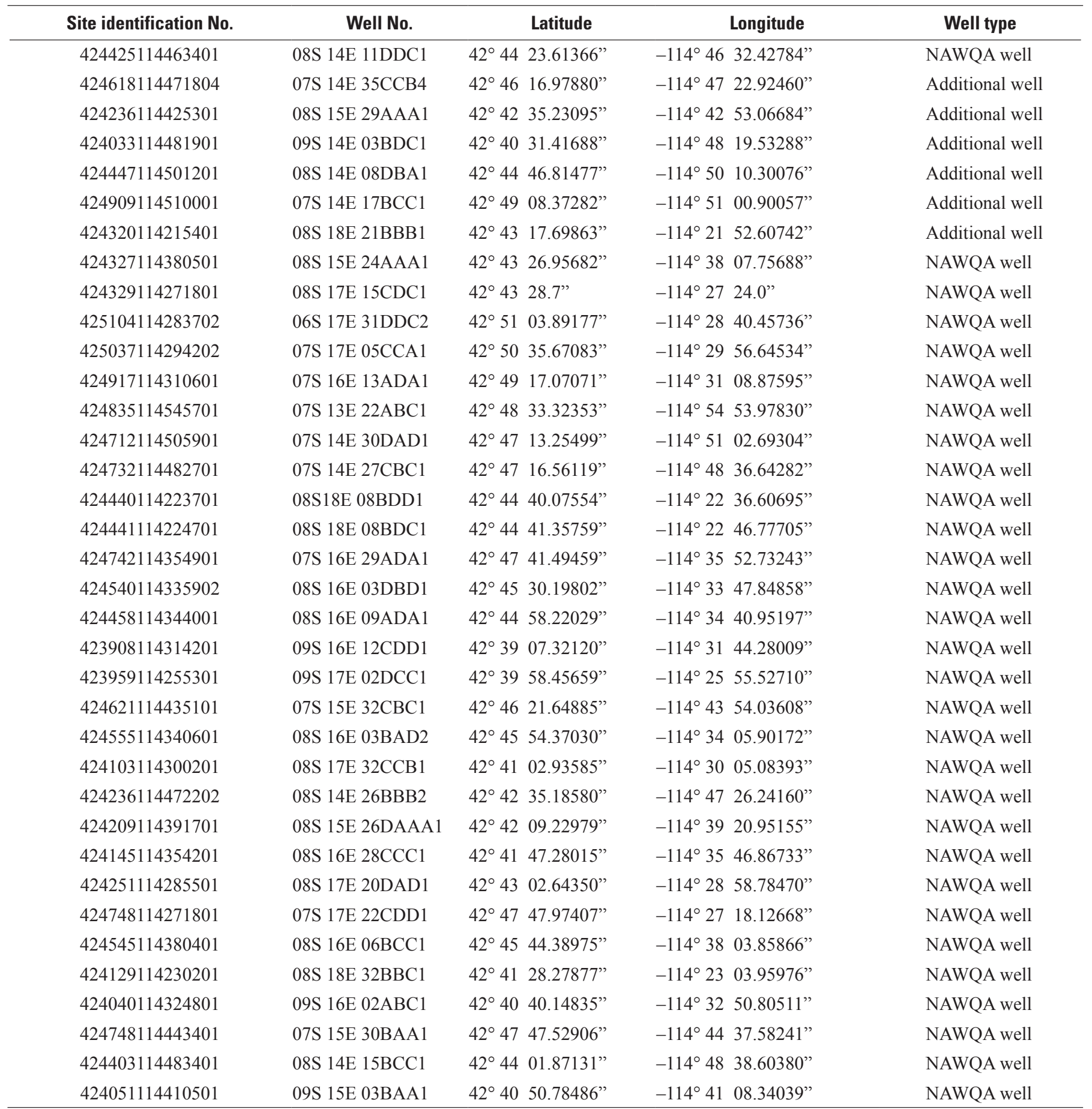


Table 2. Groundwater-quality parameters sampled from 36 wells completed in the Eastern Snake River Plain aquifer, Jerome and Gooding Counties, south-central Idaho, 2017.

[mg/L, milligram per liter; \%, per mil; $\mu \mathrm{g} / \mathrm{L}$, microgram per liter; $\mu \mathrm{S} / \mathrm{cm}$ at $25^{\circ} \mathrm{C}$, microsiemens per centimeter at 25 degrees Celsius]

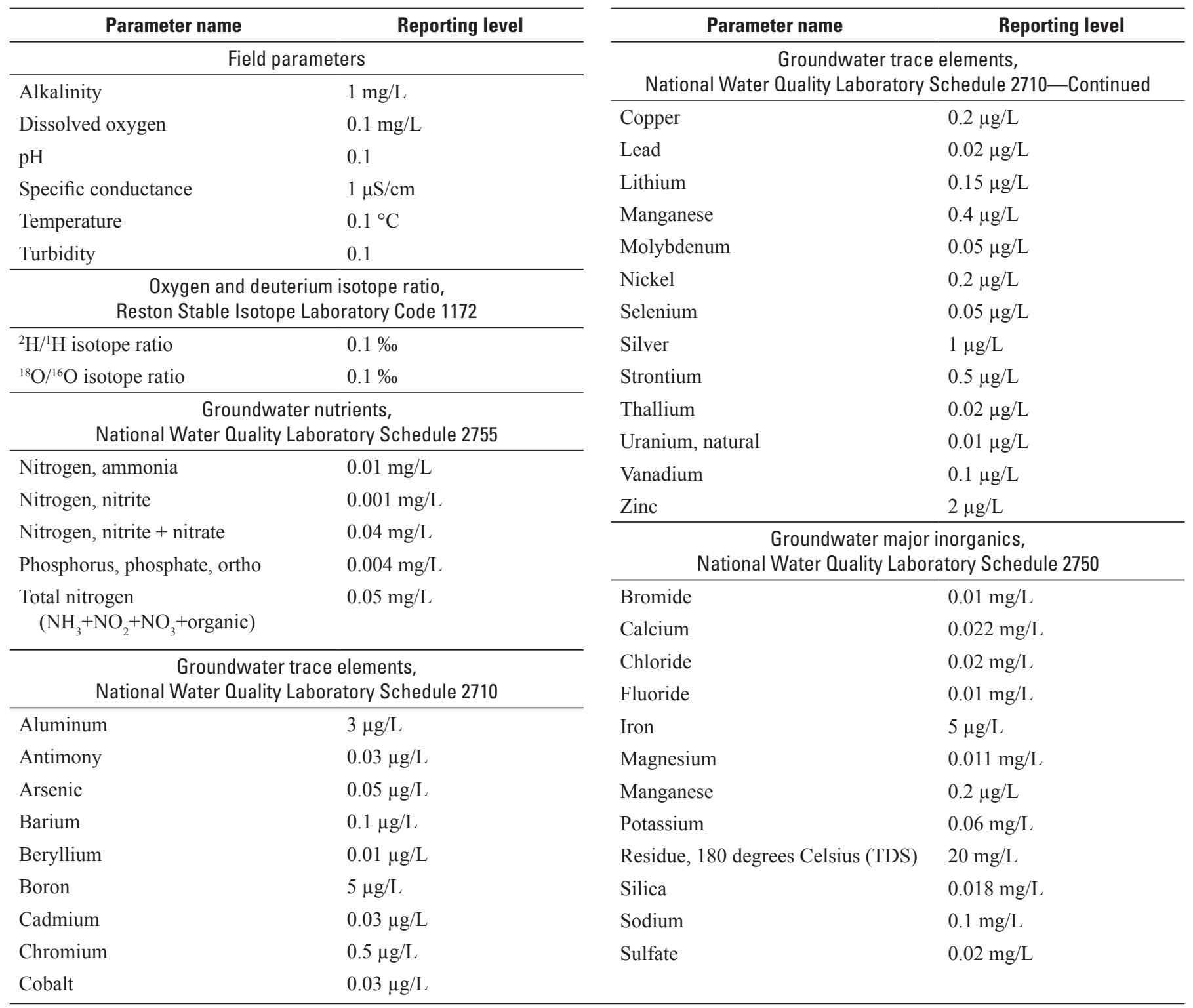




\section{Description of Study Area}

The study area is in Jerome and Gooding Counties, Idaho, which is within the western part of the ESRP (fig. 1). Land uses in the study area are primarily rangeland and agriculture. Most agricultural land in the study area is near the Snake River, a major source of water for irrigation. The climate is semiarid, and mean annual precipitation ranges from 8 to 12 in. (Skinner and Rupert, 2012).

The regional groundwater flow direction in the ESRP aquifer is to the southwest where groundwater discharges to the Snake River on the southwestern edge of the aquifer in an area called the Thousand Springs (fig. 1; Rupert and others, 2014). The study area overlies the western part of the ESRP aquifer, which is composed of a series of Quaternary vesicular and fractured olivine basalt flows of the Snake River Group (Whitehead, 1992). These basalt flows average from 20 to $25 \mathrm{ft}$ in thickness with an estimated maximum total thickness of 5,500 ft (Rupert and others, 2014). The top of the basalt generally is less than $100 \mathrm{ft}$ below land surface throughout this part of the plain. Layered basalt flows in the ESRP aquifer yield exceptionally large volumes of water to wells and springs. Individual well yields in the ESRP are some of the highest in the nation, typically ranging from 2,000 to $3,000 \mathrm{gal} / \mathrm{min}$ to as much as $7,000 \mathrm{gal} / \mathrm{min}$ with minimal drawdown (Whitehead, 1992; Lindholm, 1996). Transmissivity is commonly $100,000 \mathrm{ft}^{2} / \mathrm{d}$, and can be as high as 1,000,000 ft' $/ \mathrm{d}$ (Whitehead, 1992). Locally, aquifer properties can vary greatly; however, the variability is minimal on a regional scale.

The NAWQA well network in the study area was established because of a history of elevated nitrate concentrations in groundwater and because the area land uses are predominantly irrigated agriculture sourced by surface water and an expanding dairy industry (Rupert, 1997). The well network includes 30 wells, mostly used for domestic supply. The wells range in depth from 55 to $600 \mathrm{ft}$ (median of $222 \mathrm{ft}$ ). Most wells are cased from the surface, through the soil horizon, and a short distance into the basalts, typically 20-30 ft deep and then the wells are an open hole to the bottom of the well. Depth to water in these wells in 2017 was $47-455 \mathrm{ft}$ with a median of $150 \mathrm{ft}$.

\section{Methods}

The same methods were followed at each well. Upon arrival at a well the groundwater level was measured following the procedures of Cunningham and Schalk (2011). Then the groundwater-quality sampling and well survey were completed as described here.

\section{Groundwater-Quality Sampling}

Groundwater-quality sampling followed the protocols in the USGS National Field Manual for the Collection of Water-Quality Data (U.S. Geological Survey, variously dated) including methods for determining adequate well purge prior to sampling, such as flushing at least three well bore volumes of water prior to sampling and monitoring field parameters until stabilized. Most sites sampled in this study are domestic wells pumped often for domestic use. In these domestic wells, field parameters ( $\mathrm{pH}$, water temperature, specific conductance, dissolved oxygen, and turbidity) were measured every 5 minutes until stable indicating an adequate well purge. The wells were purged for a minimum of 25 minutes prior to sampling. Four of the sampled wells were monitoring wells that are not used routinely, and therefore were pumped for a longer period to flush three bore volumes of water from the well and to attain field parameter stabilization. These wells did not have existing pumps in place, so a portable submersible pump was lowered into the well. Once the well purge was completed, water was transferred directly from the well faucet to a mobile laboratory through Teflon ${ }^{\circledR}$ tubing, and all samples were collected in an isolated processing chamber. When sampling was completed, samples were shipped overnight to the USGS National Water Quality Laboratory (NWQL) in Lakewood, Colorado, except samples for stable-isotope analysis. Stable-isotope samples were shipped to the USGS Reston Stable Isotope Laboratory (RSIL) in Reston, Virginia. A complete list of sampled constituents is shown in table 2 .

\section{Well-Elevation Surveys}

Wells were surveyed to establish accurate locations and elevations. Global navigation satellite system surveys followed the methodology described in Rydlund and Densmore (2012) for using a real-time network. Wherever possible, wells were surveyed at the groundwater-level measuring point (MP). The MP is typically located inside the well at the top of the casing. At wells where the MP could not be surveyed due to satellite obstructions (for example, when the well was near a tree or building), the ground surface was surveyed as close to the well as possible. Ground-surface elevation is determined by subtracting the MP height (distance between the MP and the ground surface) from the surveyed elevation. When a MP could not be surveyed directly, the ground-surface elevation was reported directly from the surveyed elevation. 


\section{Quality Assurance and Quality Control Groundwater Levels}

All samples were collected following quality-assurance and quality-control protocols described in the USGS National Field Manual for the Collection of Water-Quality Data (U.S. Geological Survey, variously dated). All samples, except those for stable-isotope analysis were analyzed by the USGS National Water Quality Laboratory (NWQL), which uses a Quality Management System (D.L. Stevenson, U.S. Geological Survey, unpub. data, 2013) and Quality Assurance and Quality Control Manual (D.L. Stevenson and A.R. Barnard, U.S. Geological Survey, unpub. data, 2013) as guidelines for the analytical work conducted at the laboratory. Stable-isotope samples were analyzed by RSIL following protocols described by Révész and Coplen (2008a, 2008b).

The bias and precision of groundwater-quality sample results were evaluated through the collection of an equipment blank, two field blanks, and a sequential replicate sample. An equipment blank was collected prior to sampling to verify the cleanliness of the equipment used for sampling. Two field blanks were collected at different dates throughout the sampling effort with the second field blank coinciding with the collection of a sequential replicate sample.

The equipment blank sample results were less than the NWQL reporting levels for all constituents except a copper concentration of $6.3 \mu \mathrm{g} / \mathrm{L}$ and a zinc concentration of $2.9 \mu \mathrm{g} / \mathrm{L}$. The subsequent field blank indicated the copper concentration decreased to $0.43 \mu \mathrm{g} / \mathrm{L}$ and zinc was less than the NWQL reporting level. All other field blank values were less than the NWQL reporting level, as were all constituents measured for the second field blank.

The sequential replicate sample was collected on the same date as the second field blank. The constituents with the highest percent differences between the original field sample and the sequential replicate sample were zinc (21 percent), boron (15 percent), lithium (10 percent), strontium (8 percent), chromium ( 8 percent), total nitrogen ( 7 percent), arsenic (6 percent), and barium (5 percent). All other values were less than 5 percent difference between the original field sample and sequential replicate sample or the constituents were less than the laboratory reporting levels hence not comparable.

\section{Results}

All groundwater-quality and water-level results are available in appendix 1 and online at the USGS National Water Information System (NWIS) at https://waterdata.usgs. gov/nwis. NWIS includes a map interface to search for sites and data (https://maps.waterdata.usgs.gov/mapper/index. html). Groundwater-quality and level data can be viewed and downloaded by site(s) using site identification No.(s) (table 1) at https://nwis.waterdata.usgs.gov/usa/nwis/qwdata and https:// nwis.waterdata.usgs.gov/usa/nwis/gwlevels, respectively.
Groundwater altitude levels (fig. 2) indicate a groundwater-flow direction from the east to west (groundwater flows from high altitude to low altitude). Well-elevation surveys are helpful in reducing errors in groundwater levels. As a result, differences in groundwater-level altitudes are better attributed to actual measured differences instead of incorporated well-elevation errors. Groundwater levels might still contain some measurement errors, but are greatly reduced by having accurate well-elevation measurements.

\section{Groundwater Quality}

Groundwater-quality data are provided in appendix 1 and are available online at the NWIS at https://waterdata. usgs.gov/nwis as previously mentioned. Many of the groundwater-quality constituents measured for this study vary in concentration across the study area. The spatial distribution for most constituents is similar to specific conductance (fig. 3) and nitrate (fig. 4). Constituent concentrations are generally low in northwestern Jerome County through the central part of Gooding County (figs. 3 and 4). A previous study proposed that a thinning geometry of the aquifer in the study area forces an upward convergence of regional groundwater flow with local surface recharge to groundwater. In areas with less upward convergence of regional groundwater a relatively higher proportion of local recharge to groundwater from agricultural areas results in elevated concentrations of many constituents in the study area (Skinner and Rupert, 2012).

\section{Stable Isotopes}

Stable isotopes (deuterium $\left[\delta^{2} \mathrm{H}\right]$ and oxygen $\left[\delta^{18} \mathrm{O}\right]$ isotopes) provide useful information about the sources of constituents in water and(or) the evaporation conditions the source water has experienced (Kendall and McDonnell, 1998). Stable isotope results (figs. 5 and 6) show two groupings of samples results with two outliers. One outlier, shown in figures 5 and 6 (site identification No. 42471211450901), has notably high stable-isotope values and its sample was collected from a NAWQA well completed in sediments. Although this NAWQA well, being completed in sediments, differs from nearby NAWQA wells completed in basalts, it has remained in the well network to continue its long-term water-quality record. The stable isotope values of the other outlier (site identification No. 424618114471804), shown in figures 5 and 6 , are less than the other samples. This outlier was sampled from a well that is $536 \mathrm{ft}$ deep, which is much deeper than nearby wells and one of the deepest wells in the study (median well depth of $222 \mathrm{ft}$ ). 


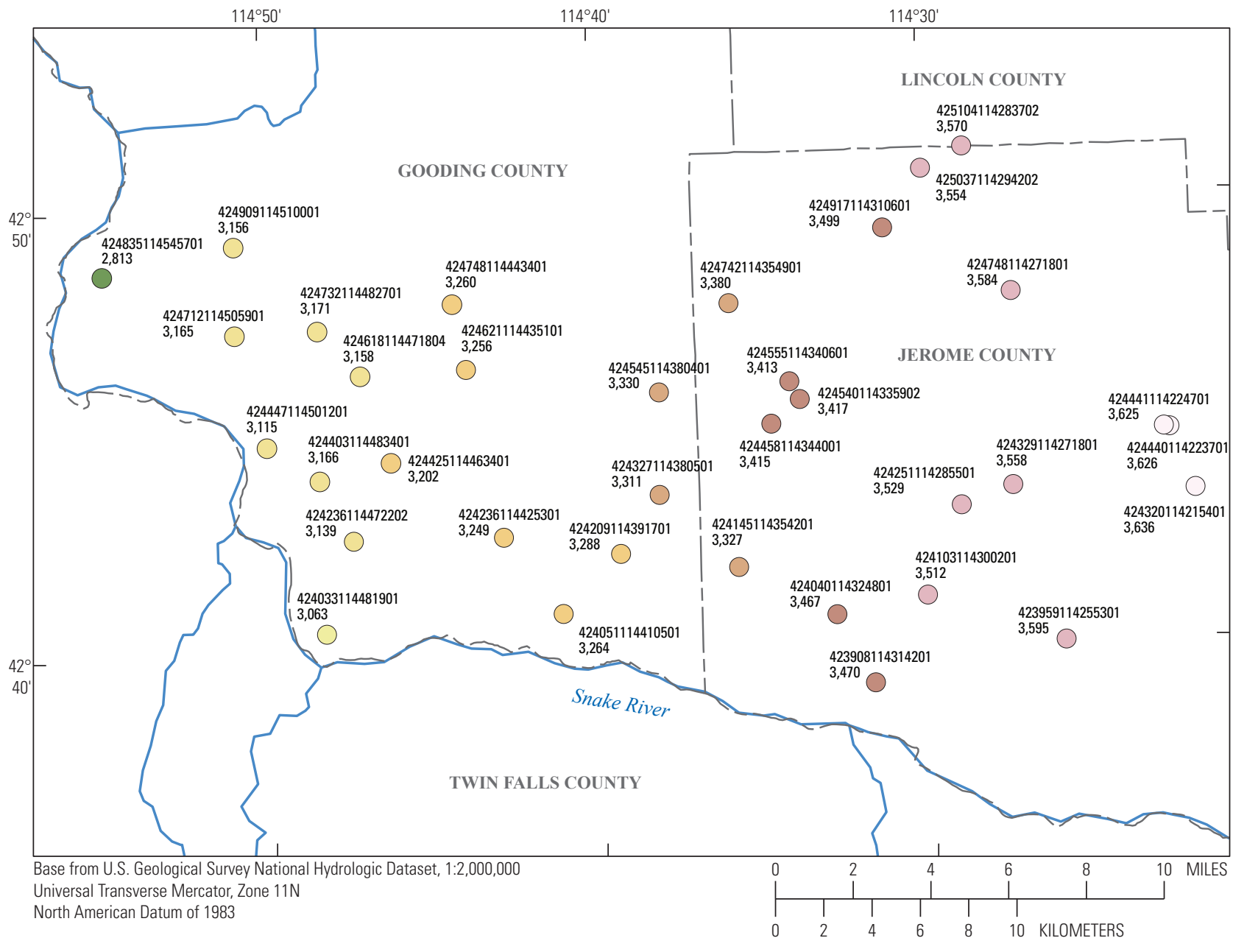

EXPLANATION

Groundwater-level altitude, in feet above the North American Vertical Datum of 1988
2,813 to 2,900
3,301 to 3,400
2,901 to 3,000
3,401 to 3,500
3,001 to 3,100
3,501 to 3,600
3,101 to 3,200
3,601 to 3,700
3,201 to 3,300

Site identification No. and altitude 424327114380501 3,311

Figure 2. Measured groundwater-level altitudes at 36 wells, Jerome and Gooding Counties, south-central Idaho. 


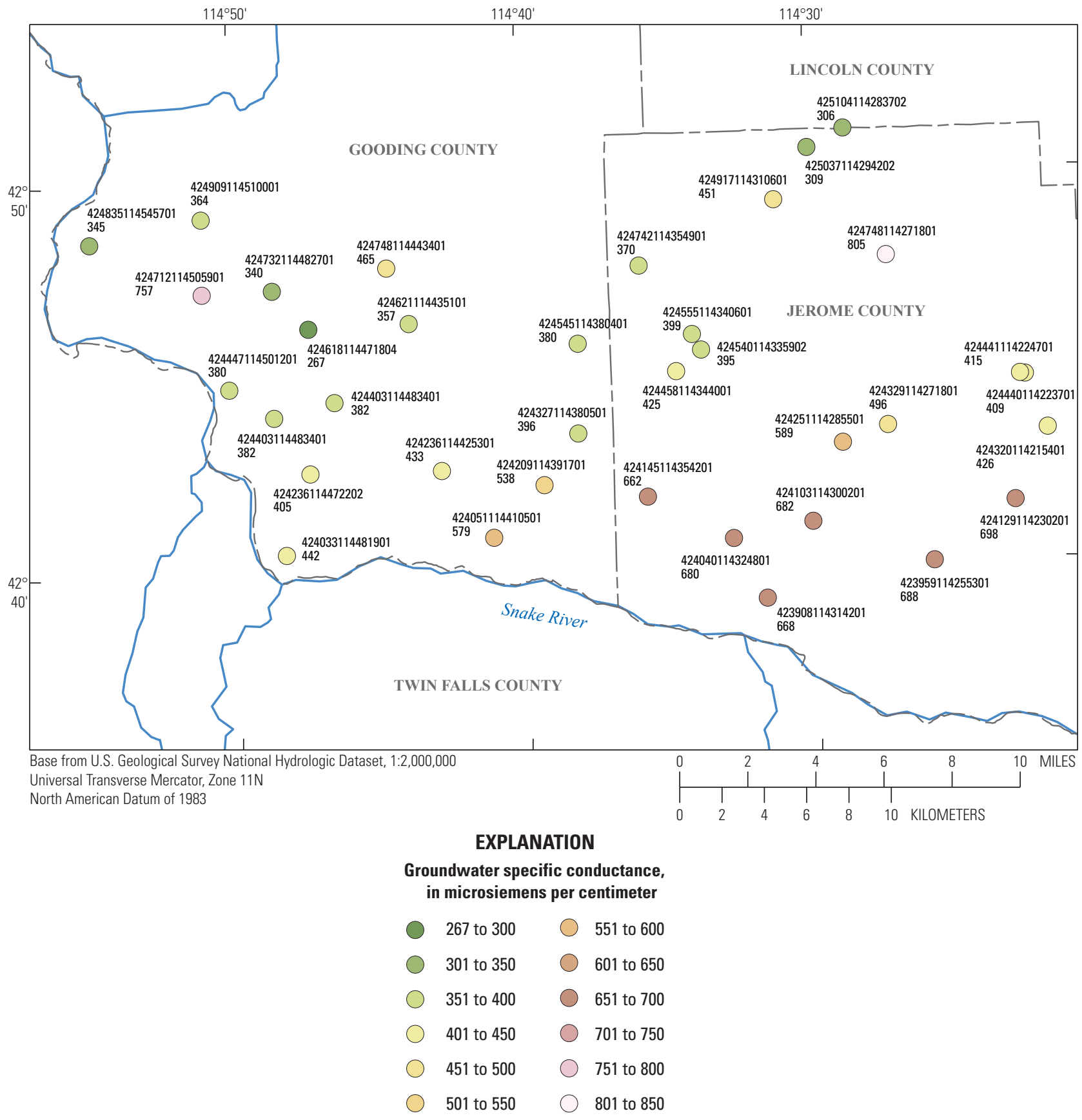

Site identification No. and specific conductance 396327114380501

Figure 3. Specific conductance measured from groundwater in 36 wells in Jerome and Gooding Counties, south-central Idaho. 


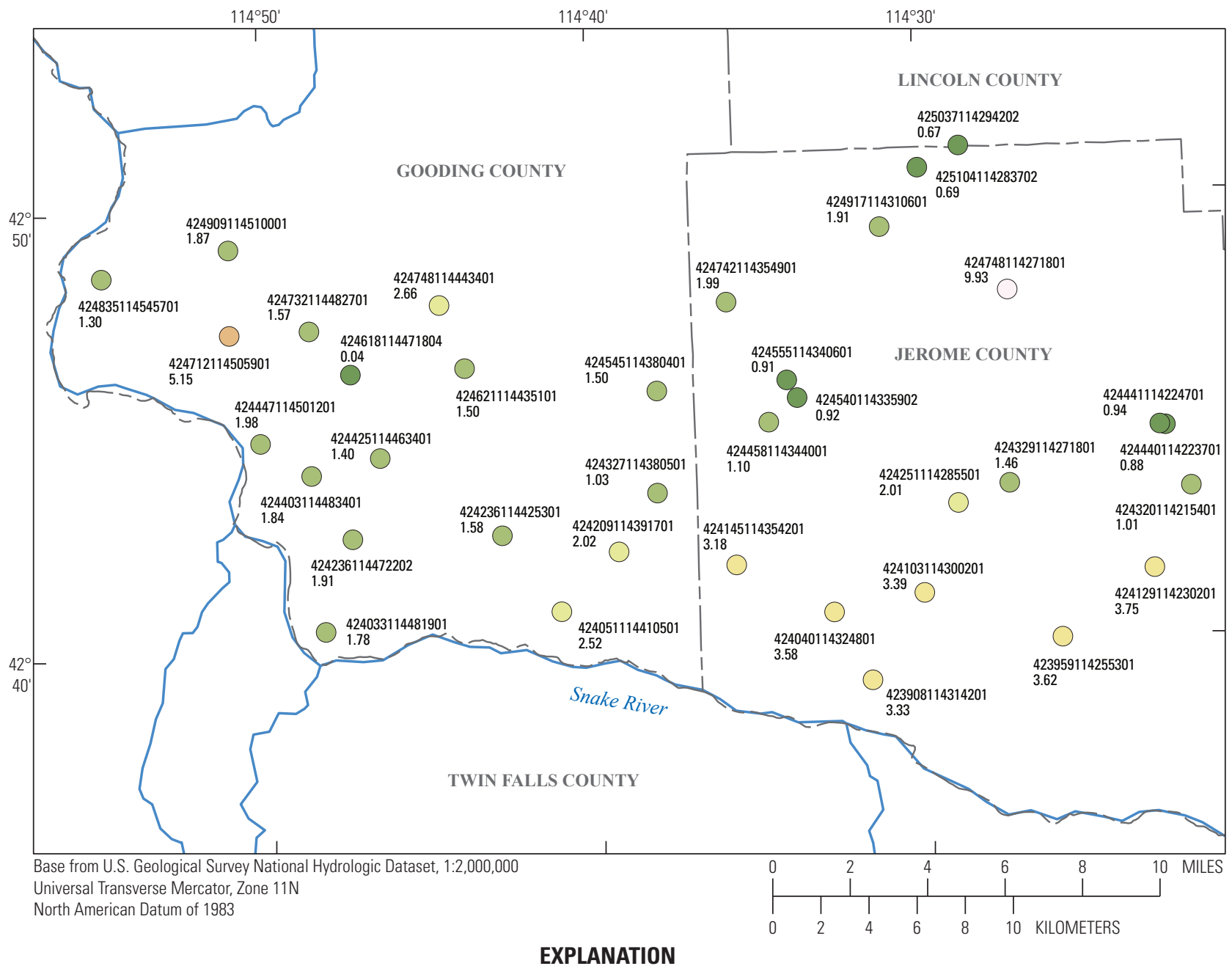

$\begin{aligned} & \text { Groundwater nitrate }\left(\mathbf{N O}_{\mathbf{2}}+\mathbf{N O}_{\mathbf{3}} \text { as } \mathbf{N}\right) \text {, } \\ & \text { in milligrams per liter }\end{aligned}$
$\begin{array}{llll}0.04 \text { to } 1.00 & 5.01 \text { to } 6.00 \\ 1.01 \text { to } 2.00 & & 6.01 \text { to } 7.00 \\ & 2.01 \text { to } 3.00 & & 7.01 \text { to } 8.00 \\ & 3.01 \text { to } 4.00 & & 8.01 \text { to } 9.00 \\ & 4.01 \text { to } 5.00 & \bigcirc & 9.01 \text { to } 10.00\end{array}$

Site identification No. and nitrate concentration 424327114380501 1.03

Figure 4. Nitrate $\left(\mathrm{NO}_{2}+\mathrm{NO}_{3}\right.$ as $\left.\mathrm{N}\right)$ from groundwater-quality samples in 36 wells in Jerome and Gooding Counties, south-central Idaho. 


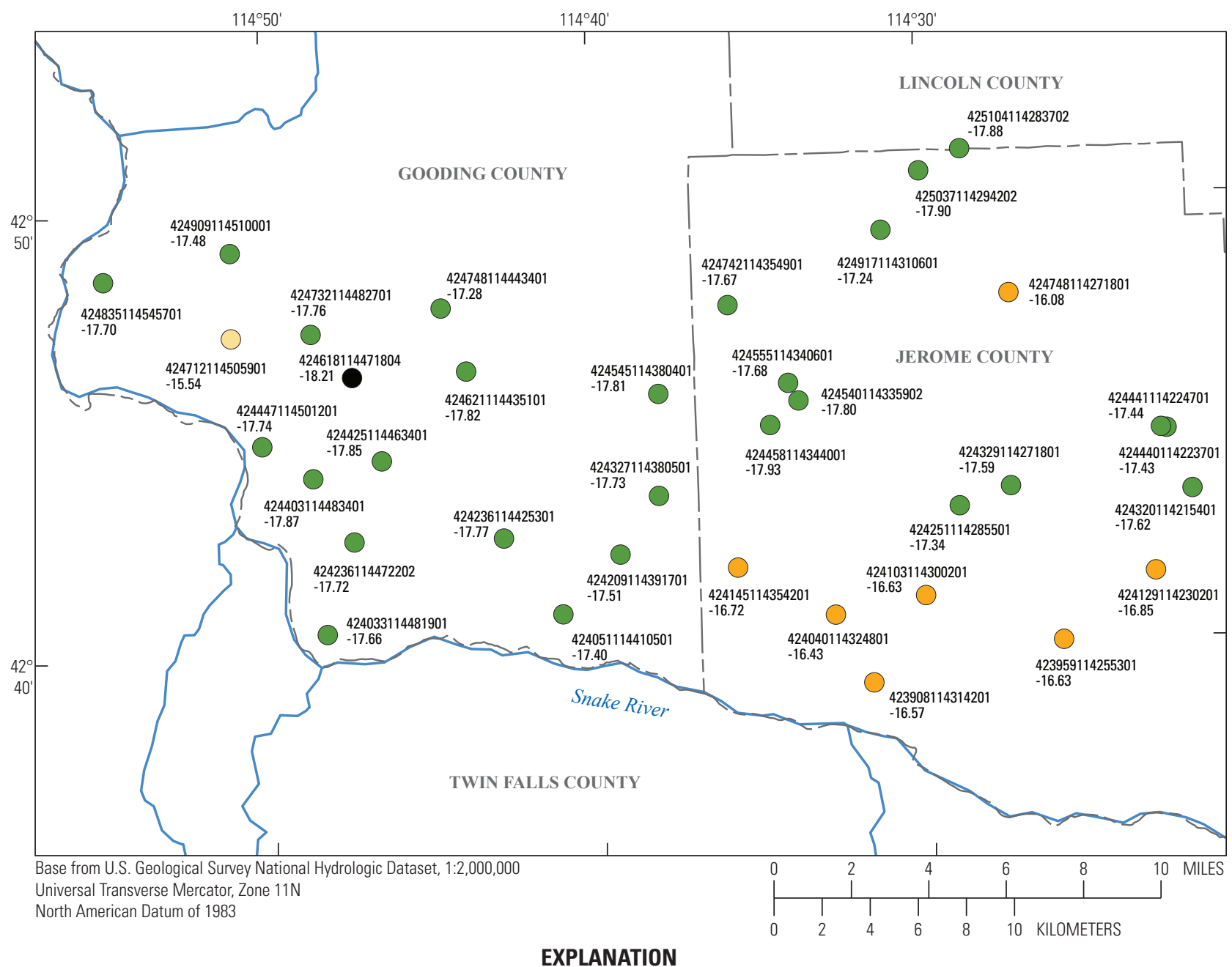

Relative oxygen stable isotope ratio $\left(\delta^{18} 0\right)$

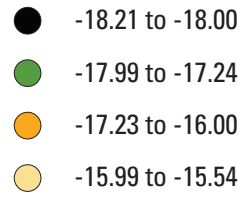

Site identification No. and $\left(\delta^{18} 0\right)$ 424327114380501

Figure 5. Relative oxygen stable isotope ratios $\left(\delta^{18} 0\right)$ from groundwater quality samples in 36 wells in Jerome and Gooding Counties, south-central Idaho. 


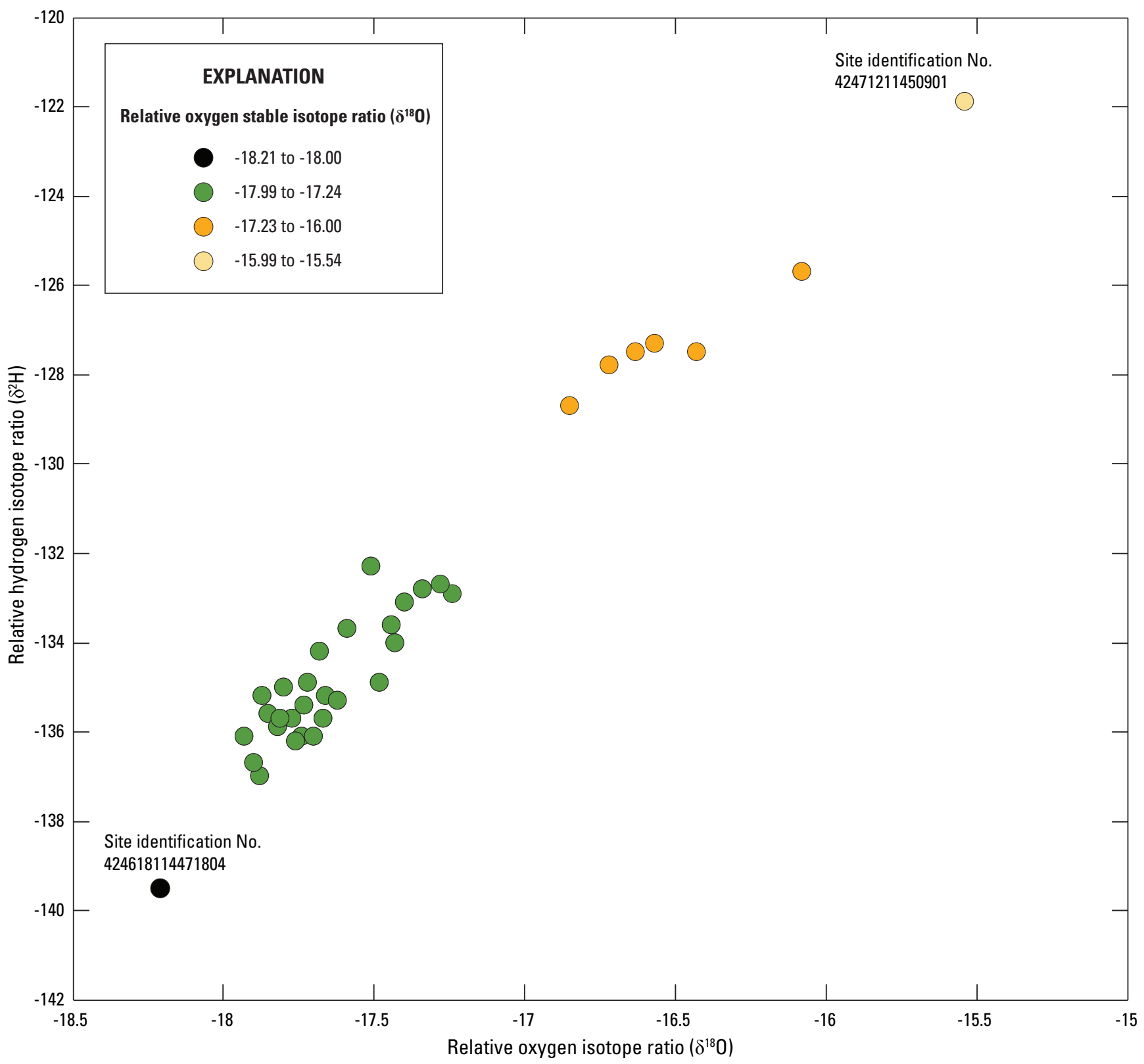

Figure 6. Stable isotope relative ratios of hydrogen and oxygen from groundwater quality samples in 36 wells in Jerome and Gooding Counties, south-central Idaho. 


\section{Acknowledgments}

This study would not have been possible without the permission of well owners in Jerome and Gooding Counties to access and sample their wells. Their cooperation is greatly appreciated.

\section{References Cited}

Cunningham, W.L., and Schalk, C.W., comps., 2011, Groundwater technical procedures of the U.S. Geological Survey: U.S. Geological Survey Techniques and Methods 1-A1, $151 \mathrm{p}$.

Kendall, C., and McDonnell, J.J., eds., 1998, Isotope tracers in catchment hydrology: Elsevier, accessed January 18, 2018, at http://wwwrcamnl.wr.usgs.gov/isoig/isopubs/itchinfo. html.

Lindholm, G.F., 1996, Summary of the Snake River Plain Regional Aquifer-System Analysis in Idaho and eastern Oregon: U.S. Geological Survey Professional Paper 1408A, 59 p., 1 pl. [Also available at http://pubs.er.usgs.gov/ publication/pp1408A.]

Révész, K., and Coplen, T.B., 2008a, Determination of the $\delta\left({ }^{2} \mathrm{H} /{ }^{1} \mathrm{H}\right)$ of water-RSIL lab code 1574 , chap. $\mathrm{C} 1$ of Révész, K., and Coplen, T.B., eds., Methods of the Reston Stable Isotope Laboratory: U.S. Geological Survey Techniques and Methods 10-C1, 27 p. [Also available at https://pubs.er.usgs.gov/publication/tm10C1.]

Révész, K., and Coplen, T., B., 2008b, Determination of the $\delta$ $\left({ }^{18} \mathrm{O} /{ }^{16} \mathrm{O}\right)$ of water-RSIL lab code 489 , chap. C2 of Révész, K., and Coplen, Tyler B., eds., Methods of the Reston Stable Isotope Laboratory: U.S. Geological Survey Techniques and Methods, 10-C2, $28 \mathrm{p}$. [Also available at https://pubs. er.usgs.gov/publication/tm10C1.]

Rowe, G.L., Jr., Belitz, K., Demas, C.R., Essaid, H.I., Gilliom, R.J., Hamilton, P.A., Hoos, A.B., Lee, C.J., Munn, M.D., and Wolock, D.W., 2013, Design of Cycle 3 of the National Water-Quality Assessment Program, 2013-23-Part 2Science plan for improved water-quality information and management: U.S. Geological Survey Open-File Report 2013-1160, 110 p., http://pubs.usgs.gov/of/2013/1160/.
Rupert, M.G., 1997, Nitrate $\left(\mathrm{NO}_{2}+\mathrm{NO}_{3}-\mathrm{N}\right)$ in ground water of the upper Snake River Basin, Idaho and Western Wyoming, 1991-95: U.S. Geological Survey Water-Resources Investigations Report 97-4174, 56 p. [Also available at https://pubs.er.usgs.gov/publication/wri974174.]

Rupert, M.G., Hunt, C.D., Jr., Skinner, K.D., Frans, L.M., and Mahler, B.J., 2014, The quality of our Nation's watersGroundwater quality in the Columbia Plateau and Snake River Plain basin-fill and basaltic-rock aquifers and the Hawaiian volcanic-rock aquifers, Washington, Idaho, and Hawaii, 1993-2005: U.S. Geological Survey Circular 1359, 88 p., https://dx.doi.org/10.3133/cir1359.

Rydlund, P.H., Jr., and Densmore, B.K., 2012, Methods of practice and guidelines for using survey-grade global navigation satellite systems (GNSS) to establish vertical datum in the United States Geological Survey: U.S. Geological Survey Techniques and Methods, book 11, chap. D1, $102 \mathrm{p}$. with appendixes. [Also available at https://pubs. er.usgs.gov/publication/tm11D1.]

Skinner, K.D., and Rupert, M.G., 2012, Numerical model simulations of nitrate concentrations in groundwater using various nitrogen input scenarios, mid-Snake region, south-central Idaho: U.S. Geological Survey Scientific Investigations Report 2012-5237, 30 p. [Also available at https://pubs.er.usgs.gov/publication/sir20125237.]

U.S. Geological Survey, variously dated, National field manual for the collection of water-quality data: U.S. Geological Survey Techniques of Water-Resources Investigations, book 9, chaps. A1-A10, accessed January 18, 2018, at http:// pubs.water.usgs.gov/twri9A.

Whitehead, R.L., 1992, Geohydrologic framework of the Snake River Plain regional aquifer system, Idaho and eastern Oregon: U.S. Geological Survey Professional Paper 1408-B, 32 p. [Also available at https://pubs.er.usgs.gov/ publication/pp1408B.] 


\section{Appendix 1. Groundwater-Quality Data from 36 Wells Completed in the Eastern Snake River Plain Aquifer, Jerome and Gooding Counties, South-Central Idaho, 2017}

[All groundwater-quality data are available online at the USGS National Water Information System (https://waterdata.usgs.gov/nwis). Groundwater-quality sampling locations and site identification Nos. are shown in figure 1. Latitude and longitude are referenced to the 2011 adjustment of the North American Datum of 1983 (NAD83 [2011]). Land-surface elevation is referenced to the North American Vertical Datum of 1988 (NAVD88). Abbreviations: CaCO ${ }_{3}$, calcium carbonate; ${ }^{\circ} \mathrm{C}$, degrees Celsius; $\mathrm{mg} / \mathrm{L}$, milligram per liter; mm/Hg, millimeter of mercury; N, nitrogen; NTRU, Nephelometric Turbidity Ratio Unit; $\mu \mathrm{S} / \mathrm{cm}$, microsiemen per centimeter; $\mu \mathrm{g} / \mathrm{L}$, microgram per liter; \%o, per mil; <, less than]

\begin{tabular}{|c|c|c|c|c|c|c|c|}
\hline $\begin{array}{c}\text { Site identification } \\
\text { No. }\end{array}$ & Well No. & $\begin{array}{c}\text { Latitude } \\
\text { (NAD83 [2011]) }\end{array}$ & $\begin{array}{c}\text { Longitude } \\
\text { (NAD83 [2011]) }\end{array}$ & $\begin{array}{c}\text { Land-surface } \\
\text { elevation } \\
\text { (NAVD88) }\end{array}$ & $\begin{array}{c}\text { Depth to } \\
\text { groundwater } \\
\text { below land } \\
\text { surface }\end{array}$ & Date & $\begin{array}{c}\text { Sample } \\
\text { time }\end{array}$ \\
\hline 424425114463401 & 08S 14E 11DDC1 & $42^{\circ} 44^{\prime} 23.61366^{\prime \prime}$ & $-114^{\circ} 46^{\prime} 32.42784^{\prime \prime}$ & $3,275.42$ & 75.26 & $6 / 13 / 2017$ & 1000 \\
\hline 424618114471804 & 07S 14E 35CCB4 & $42^{\circ} 46^{\prime} 16.97880^{\prime \prime}$ & $-114^{\circ} 47^{\prime} 22.92460^{\prime \prime}$ & $3,282.79$ & 125.89 & $6 / 13 / 2017$ & 1230 \\
\hline 424236114425301 & 08S 15E 29AAA1 & $42^{\circ} 42^{\prime} 35.23095^{\prime \prime}$ & $-114^{\circ} 42^{\prime} 53.06684^{\prime \prime}$ & $3,323.87$ & 75.52 & $6 / 13 / 2017$ & 1400 \\
\hline 424909114510001 & 07S 14E 17BCC1 & $42^{\circ} 49^{\prime} 08.37282^{\prime \prime}$ & $-114^{\circ} 51^{\prime} 00.90057^{\prime \prime}$ & $3,281.37$ & 126.91 & $6 / 14 / 2017$ & 1600 \\
\hline 424320114215401 & 08S 18E 21BBB1 & $42^{\circ} 43^{\prime} 17.69863^{\prime \prime}$ & $-114^{\circ} 21^{\prime} 52.60742^{\prime \prime}$ & $3,912.55$ & 278.88 & $6 / 15 / 2017$ & 0900 \\
\hline 424327114380501 & 08S 15E 24AAA1 & $42^{\circ} 43^{\prime} 26.95682^{\prime \prime}$ & $-114^{\circ} 38^{\prime} 07.75688^{\prime \prime}$ & $3,469.46$ & 159.15 & $6 / 12 / 2017$ & 1130 \\
\hline 424329114271801 & 08S 17E 15CDC1 & $\left({ }^{1}\right)$ & $\left({ }^{1}\right)$ & $\left({ }^{1}\right)$ & 455.42 & $6 / 12 / 2017$ & 1500 \\
\hline 424712114505901 & 07S 14E 30DAD1 & $42^{\circ} 47^{\prime} 13.25499^{\prime \prime}$ & -114 $51^{\prime} 02.69304^{\prime \prime}$ & $3,246.16$ & 81.92 & $6 / 19 / 2017$ & 1330 \\
\hline 424732114482701 & 07S 14E 27CBC1 & $42^{\circ} 47^{\prime} 16.56119^{\prime \prime}$ & $-114^{\circ} 48^{\prime} 36.64282^{\prime \prime}$ & $3,293.80$ & 123.21 & $6 / 19 / 2017$ & 1600 \\
\hline 424440114223701 & 08S 18E 08BDD1 & $42^{\circ} 44^{\prime} 40.07554^{\prime \prime}$ & $-114^{\circ} 22^{\prime} 36.60695^{\prime \prime}$ & $3,989.71$ & 364.88 & $6 / 20 / 2017$ & 0900 \\
\hline 424441114224701 & 08S 18E 08BDC1 & $42^{\circ} 44^{\prime} 41.35759^{\prime \prime}$ & $-114^{\circ} 22^{\prime} 46.77705^{\prime \prime}$ & $3,995.09$ & 371.48 & $6 / 20 / 2017$ & 1100 \\
\hline 424742114354901 & 07S 16E 29ADA1 & $42^{\circ} 47^{\prime} 41.49459^{\prime \prime}$ & $-114^{\circ} 35^{\prime} 52.73243^{\prime \prime}$ & $3,604.45$ & 226.27 & $6 / 21 / 2017$ & 0930 \\
\hline 424540114335902 & 08S 16E 03DBD1 & $42^{\circ} 45^{\prime} 30.19802^{\prime \prime}$ & $-114^{\circ} 33^{\prime} 47.84858^{\prime \prime}$ & $3,651.21$ & 235.95 & $6 / 21 / 2017$ & 1400 \\
\hline 424458114344001 & 08S 16E 09ADA1 & $42^{\circ} 44^{\prime} 58.22029^{\prime \prime}$ & $-114^{\circ} 34^{\prime} 40.95197^{\prime \prime}$ & $3,600.18$ & 187.43 & $6 / 21 / 2017$ & 1600 \\
\hline 423908114314201 & 09S 16E 12CDD1 & $42^{\circ} 39^{\prime} 07.32120^{\prime \prime}$ & $-114^{\circ} 31^{\prime} 44.28009^{\prime \prime}$ & $3,596.80$ & 127.61 & $6 / 22 / 2017$ & 1430 \\
\hline 423959114255301 & 09S 17E 02DCC1 & $42^{\circ} 39^{\prime} 58.45659^{\prime \prime}$ & $-114^{\circ} 25^{\prime} 55.52710^{\prime \prime}$ & $3,743.88$ & 149.64 & $6 / 22 / 2017$ & 1600 \\
\hline 424748114271801 & 07S 17E 22CDD1 & $42^{\circ} 47^{\prime} 47.97407^{\prime \prime}$ & $-114^{\circ} 27^{\prime} 18.12668^{\prime \prime}$ & $3,893.30$ & 311.17 & $6 / 20 / 2017$ & 1600 \\
\hline 424545114380401 & 08S 16E 06BCC1 & $42^{\circ} 45^{\prime} 44.38975^{\prime \prime}$ & $-114^{\circ} 38^{\prime} 03.85866^{\prime \prime}$ & $3,480.51$ & 151.35 & $6 / 21 / 2017$ & 1200 \\
\hline 424129114230201 & 08S 18E 32BBC1 & $42^{\circ} 41^{\prime} 28.27877^{\prime \prime}$ & $-114^{\circ} 23^{\prime} 03.95976^{\prime \prime}$ & $3,861.01$ & $\left(^{2}\right)$ & $6 / 22 / 2017$ & 0930 \\
\hline 424040114324801 & 09S 16E 02ABC1 & $42^{\circ} 40^{\prime} 40.14835^{\prime \prime}$ & $-114^{\circ} 32^{\prime} 50.80511^{\prime \prime}$ & $3,604.19$ & 137.47 & $6 / 22 / 2017$ & 1200 \\
\hline 424748114443401 & 07S 15E 30BAA1 & $42^{\circ} 47^{\prime} 47.52906^{\prime \prime}$ & $-114^{\circ} 44^{\prime} 37.58241^{\prime \prime}$ & $3,407.21$ & 147.53 & $6 / 27 / 2017$ & 0930 \\
\hline 424403114483401 & 08S 14E 15BCC1 & $42^{\circ} 44^{\prime} 01.87131^{\prime \prime}$ & $-114^{\circ} 48^{\prime} 38.60380^{\prime \prime}$ & $3,212.47$ & 46.88 & $6 / 28 / 2017$ & 0930 \\
\hline 424051114410501 & 09S 15E 03BAA1 & $42^{\circ} 40^{\prime} 50.78486^{\prime \prime}$ & $-114^{\circ} 41^{\prime} 08.34039^{\prime \prime}$ & $3,381.32$ & 118.15 & $6 / 28 / 2017$ & 1330 \\
\hline
\end{tabular}

${ }^{1}$ Could not survey.

${ }^{2}$ Could not measure. 
Appendix 1. Groundwater-quality data from 36 wells completed in the eastern Snake River Plain Aquifer, Jerome and Gooding Counties, south-central Idaho, 2017.-Continued

\begin{tabular}{|c|c|c|c|c|c|c|c|}
\hline $\begin{array}{c}\text { Site identification } \\
\text { No. }\end{array}$ & $\begin{array}{c}\text { Air pressure, } \\
\mathrm{mm} / \mathrm{Hg}\end{array}$ & $\begin{array}{l}\text { Dissolved } \\
\text { oxygen, } \\
\text { mg/L }\end{array}$ & pH & $\begin{array}{c}\text { Specific } \\
\text { conductance, } \\
\mu \mathrm{S} / \mathrm{cm} \text { at } 25^{\circ} \mathrm{C}\end{array}$ & $\begin{array}{c}\text { Temperature, } \\
\text { water, }{ }^{\circ} \mathrm{C}\end{array}$ & $\begin{array}{l}\text { Turbidity, } \\
\text { NTRU }\end{array}$ & $\begin{array}{c}\text { Dissolved solids } \\
\text { dried at } 180^{\circ} \mathrm{C} \text {, } \\
\text { in } \mathrm{mg} / \mathrm{L}\end{array}$ \\
\hline 424425114463401 & 680 & 7.4 & 7.8 & 373 & 15.1 & 0.2 & 241 \\
\hline 424618114471804 & 681 & 0.0 & 8.4 & 267 & 17.1 & 39.2 & 204 \\
\hline 424236114425301 & 680 & 7.4 & 7.8 & 433 & 15.1 & 0.6 & 278 \\
\hline 424033114481901 & 684 & 5.5 & 7.8 & 442 & 16.9 & 14.0 & 279 \\
\hline 424909114510001 & 680 & 7.2 & 7.8 & 364 & 17.3 & 2.0 & 237 \\
\hline 424320114215401 & 666 & 7.8 & 8.0 & 426 & 14.5 & 1.0 & 275 \\
\hline 424327114380501 & 669 & 7.3 & 7.8 & 396 & 14.7 & 0.3 & 242 \\
\hline 424329114271801 & 658 & 7.5 & 7.9 & 496 & 14.7 & 1.8 & 308 \\
\hline 425104114283702 & 664 & 7.1 & 8.2 & 306 & 14.5 & 1.0 & 203 \\
\hline 424712114505901 & 684 & 7.1 & 7.4 & 757 & 15.8 & 4.0 & 485 \\
\hline 424732114482701 & 681 & 7.1 & 7.9 & 340 & 16.0 & 0.5 & 220 \\
\hline 424440114223701 & 665 & 7.7 & 8.0 & 409 & 14.8 & 0.4 & 275 \\
\hline 424441114224701 & 665 & 7.7 & 8.0 & 415 & 14.5 & 0.4 & 268 \\
\hline 424742114354901 & 674 & 7.6 & 7.8 & 370 & 16.8 & 0.3 & 231 \\
\hline 424540114335902 & 672 & 7.6 & 7.9 & 395 & 15.9 & 2.5 & 255 \\
\hline 424458114344001 & 673 & 7.7 & 7.9 & 425 & 15.8 & 0.4 & 274 \\
\hline 423908114314201 & 675 & 7.5 & 7.6 & 668 & 15.7 & 0.3 & 432 \\
\hline 423959114255301 & 672 & 7.3 & 7.7 & 688 & 15.5 & 0.4 & 459 \\
\hline 424748114271801 & 664 & 7.7 & 7.4 & 805 & 14.7 & 0.6 & 513 \\
\hline 424545114380401 & 677 & 7.7 & 7.7 & 380 & 15.0 & 0.3 & 246 \\
\hline 424129114230201 & 671 & 7.8 & 7.7 & 698 & 14.8 & 0.4 & 453 \\
\hline 424040114324801 & 677 & 7.6 & 7.5 & 680 & 15.8 & 0.4 & 438 \\
\hline 424748114443401 & 678 & 7.4 & 7.5 & 465 & 16.8 & 0.5 & 283 \\
\hline 424403114483401 & 680 & 7.6 & 7.8 & 382 & 15.7 & 0.4 & 245 \\
\hline 424051114410501 & 676 & 7.8 & 7.7 & 579 & 15.1 & 0.3 & 362 \\
\hline
\end{tabular}


Appendix 1. Groundwater-quality data from 36 wells completed in the eastern Snake River Plain Aquifer, Jerome and Gooding Counties, south-central Idaho, 2017.-Continued

\begin{tabular}{|c|c|c|c|c|c|c|c|}
\hline $\begin{array}{c}\text { Site identification } \\
\text { No. }\end{array}$ & $\begin{array}{l}\text { Calcium, mg/L } \\
\text { (water filtered) }\end{array}$ & $\begin{array}{l}\text { Magnesium, mg/L } \\
\text { (water filtered) }\end{array}$ & $\begin{array}{c}\text { Potassium, } \\
\text { mg/L } \\
\text { (water } \\
\text { filtered) }\end{array}$ & $\begin{array}{l}\text { Sodium, mg/L } \\
\text { (water filtered) }\end{array}$ & $\begin{array}{c}\text { Alkalinity, } \\
\text { mg/L CaCO } \\
\text { (water filtered) }\end{array}$ & $\begin{array}{l}\text { Bicarbonate, } \\
\text { mg/L (water } \\
\text { filtered) }\end{array}$ & $\begin{array}{c}\text { Bromide, } \\
\text { mg/L (water } \\
\text { filtered) }\end{array}$ \\
\hline 424425114463401 & 34.02 & 16.19 & 3.45 & 18.6 & 132 & 160 & 0.03 \\
\hline 424618114471804 & 23.79 & 4.60 & 7.59 & 21.3 & 100 & 120 & 0.02 \\
\hline 424236114425301 & 40.16 & 17.32 & 3.72 & 21.8 & 142 & 172 & 0.06 \\
\hline 424447114501201 & 33.14 & 16.82 & 3.55 & 18.0 & 135 & 164 & 0.03 \\
\hline 424909114510001 & 31.85 & 16.52 & 3.58 & 17.8 & 130 & 157 & 0.03 \\
\hline 424320114215401 & 40.05 & 15.89 & 3.68 & 21.5 & 135 & 163 & 0.05 \\
\hline 424327114380501 & 36.83 & 16.56 & 3.61 & 19.7 & 125 & 152 & 0.04 \\
\hline 424329114271801 & 46.94 & 18.44 & 4.21 & 25.6 & 146 & 176 & 0.09 \\
\hline 424835114545701 & 30.87 & 15.61 & 3.48 & 16.2 & 134 & 162 & 0.02 \\
\hline 424712114505901 & 79.10 & 33.54 & 4.53 & 30.8 & 279 & 338 & 0.04 \\
\hline 424732114482701 & 29.76 & 14.95 & 3.40 & 16.3 & 116 & 140 & 0.02 \\
\hline 424440114223701 & 38.56 & 15.98 & 3.69 & 20.9 & 126 & 152 & 0.04 \\
\hline 424441114224701 & 39.07 & 16.24 & 3.71 & 20.9 & 140 & 169 & 0.04 \\
\hline 424742114354901 & 32.16 & 16.33 & 3.42 & 17.7 & 128 & 155 & 0.03 \\
\hline 424540114335902 & 35.90 & 15.86 & 3.46 & 19.2 & 134 & 162 & 0.04 \\
\hline 424458114344001 & 38.77 & 16.46 & 3.64 & 20.5 & 136 & 164 & 0.06 \\
\hline 423908114314201 & 64.32 & 24.50 & 6.11 & 36.7 & 194 & 235 & 0.11 \\
\hline 423959114255301 & 64.01 & 24.27 & 6.14 & 39.9 & 197 & 239 & 0.12 \\
\hline 424251114285501 & 55.15 & 21.38 & 4.84 & 31.9 & 159 & 192 & 0.11 \\
\hline 424748114271801 & 78.17 & 34.63 & 5.20 & 40.3 & 253 & 308 & 0.07 \\
\hline 424545114380401 & 33.52 & 16.47 & 3.37 & 18.4 & 136 & 165 & 0.03 \\
\hline 424129114230201 & 66.70 & 25.32 & 5.52 & 41.5 & 201 & 244 & 0.12 \\
\hline 424040114324801 & 64.29 & 25.31 & 5.51 & 37.3 & 211 & 256 & 0.11 \\
\hline 424748114443401 & 45.62 & 19.77 & 4.05 & 19.5 & 171 & 208 & 0.02 \\
\hline 424403114483401 & 34.56 & 16.81 & 3.54 & 19.0 & 146 & 176 & 0.03 \\
\hline 424051114410501 & 54.58 & 21.96 & 4.70 & 31.1 & 166 & 201 & 0.10 \\
\hline
\end{tabular}


Appendix 1. Groundwater-quality data from 36 wells completed in the eastern Snake River Plain Aquifer, Jerome and Gooding Counties, south-central Idaho, 2017.-Continued

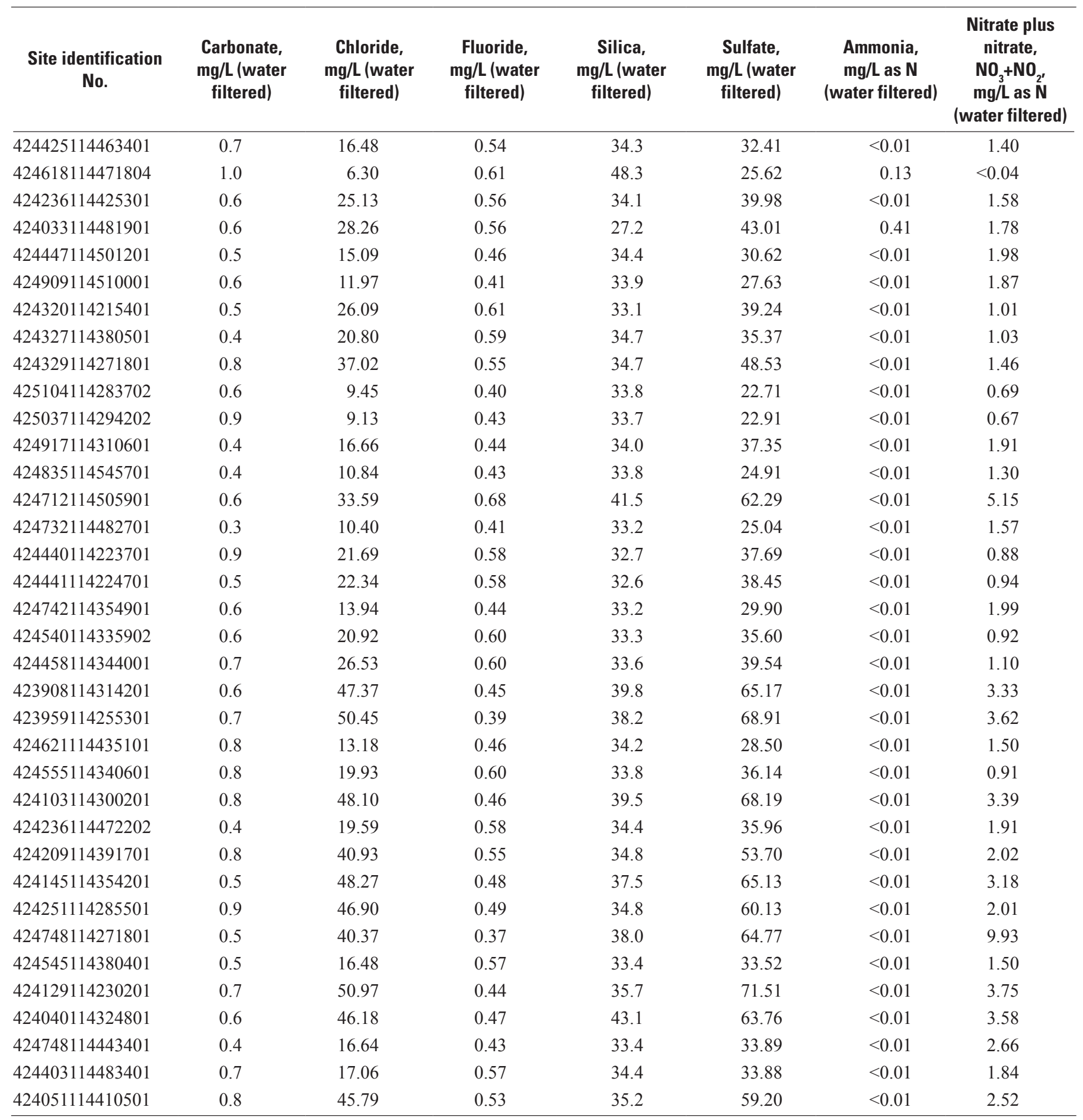


Appendix 1. Groundwater-quality data from 36 wells completed in the eastern Snake River Plain Aquifer, Jerome and Gooding Counties, south-central Idaho, 2017.-Continued

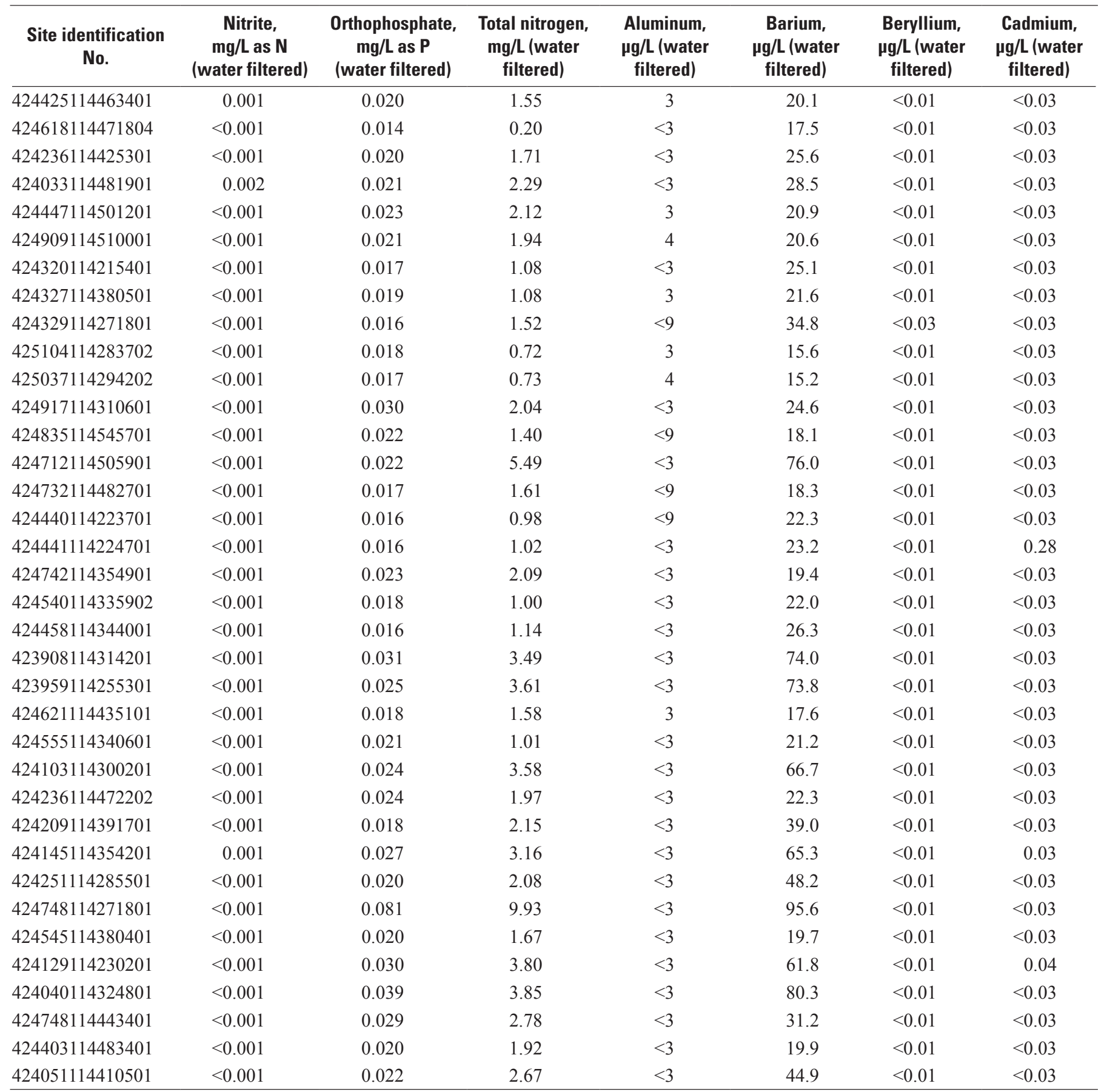


Appendix 1. Groundwater-quality data from 36 wells completed in the eastern Snake River Plain Aquifer, Jerome and Gooding Counties, south-central Idaho, 2017.-Continued

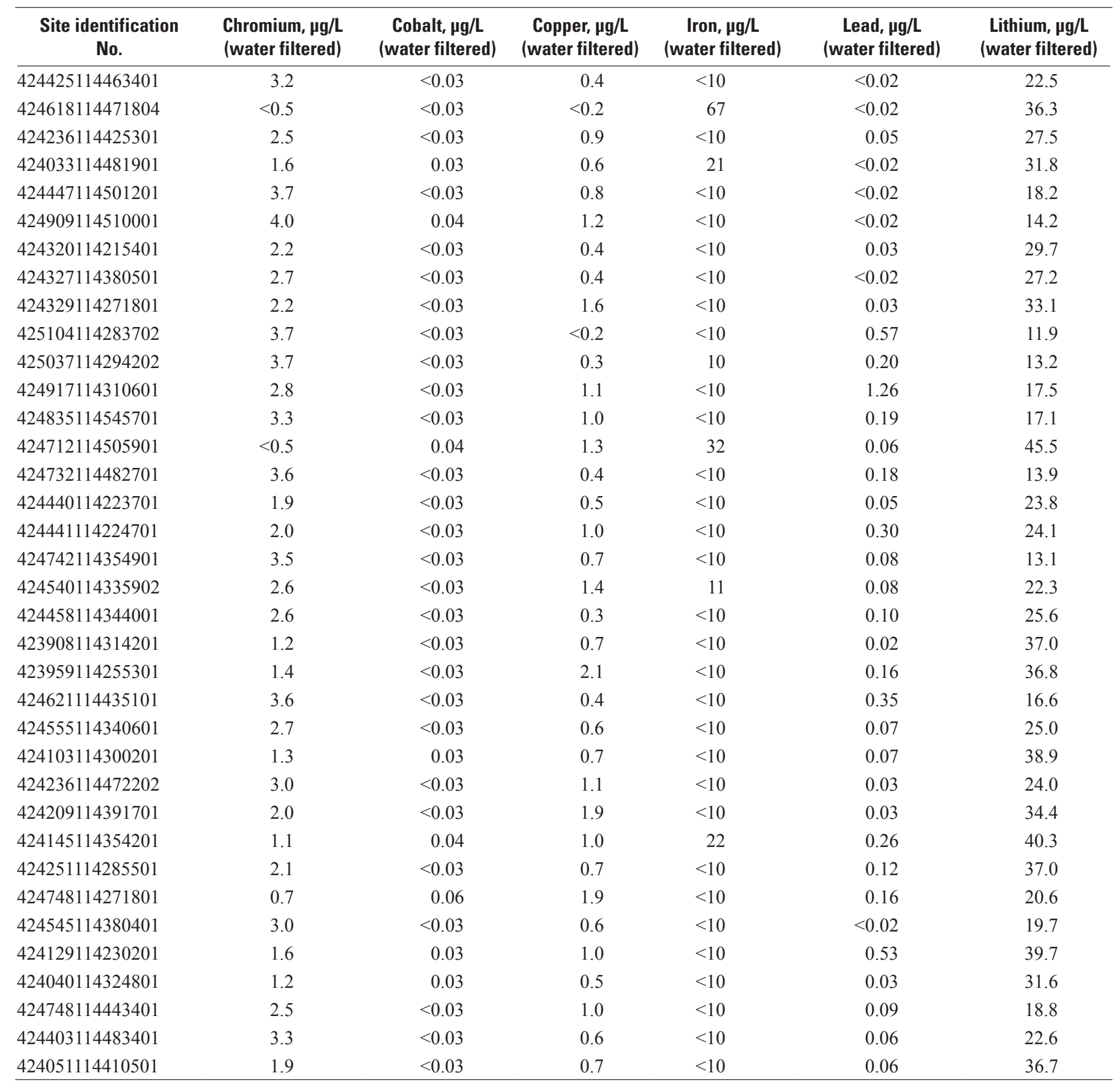


Appendix 1. Groundwater-quality data from 36 wells completed in the eastern Snake River Plain Aquifer, Jerome and Gooding Counties, south-central Idaho, 2017.-Continued

\begin{tabular}{|c|c|c|c|c|c|c|c|c|}
\hline $\begin{array}{c}\text { Site identification } \\
\text { No. }\end{array}$ & $\begin{array}{l}\text { Manganese, } \\
\boldsymbol{\mu g} / \mathrm{L} \text { (water } \\
\text { filtered) }\end{array}$ & $\begin{array}{c}\text { Molybdenum, } \\
\mu \mathrm{g} / \mathrm{L} \text { (water } \\
\text { filtered) }\end{array}$ & $\begin{array}{l}\text { Nickel, } \\
\text { pg/L (water } \\
\text { filtered) }\end{array}$ & $\begin{array}{c}\text { Silver, } \\
\mu \mathrm{g} / \mathrm{L} \text { (water } \\
\text { filtered) }\end{array}$ & $\begin{array}{l}\text { Strontium, } \\
\boldsymbol{\mu g} / \mathrm{L} \text { (water } \\
\text { filtered) }\end{array}$ & $\begin{array}{l}\text { Thallium, } \\
\mu \mathrm{g} / \mathrm{L} \text { (water } \\
\text { filtered) }\end{array}$ & $\begin{array}{c}\text { Vanadium, } \\
\mu \mathrm{g} / \mathrm{L} \text { (water } \\
\text { filtered) }\end{array}$ & $\begin{array}{c}\text { Zinc, } \\
\mu \mathrm{g} / \mathrm{L} \text { (water } \\
\text { filtered) }\end{array}$ \\
\hline 424425114463401 & $<0.4$ & 2.55 & 0.3 & $<1$ & 201 & $<0.02$ & 8.2 & 3 \\
\hline 424618114471804 & 31.7 & 4.71 & $<0.2$ & $<1$ & 184 & $<0.02$ & $<0.1$ & $<2$ \\
\hline 424236114425301 & $<0.4$ & 2.28 & $<0.2$ & $<1$ & 233 & $<0.02$ & 8.0 & 8 \\
\hline 424033114481901 & 17.5 & 2.60 & 0.6 & $<1$ & 184 & $<0.02$ & 5.6 & $<2$ \\
\hline 424447114501201 & $<0.4$ & 2.69 & 0.4 & $<1$ & 176 & $<0.02$ & 8.8 & $<2$ \\
\hline 424909114510001 & $<0.4$ & 2.69 & 0.6 & $<1$ & 176 & $<0.02$ & 8.2 & $<2$ \\
\hline 424320114215401 & $<0.4$ & 2.24 & $<0.2$ & $<1$ & 196 & $<0.02$ & 7.2 & 13 \\
\hline 424327114380501 & $<0.4$ & 2.27 & $<0.2$ & $<1$ & 196 & $<0.02$ & 7.9 & 16 \\
\hline 424329114271801 & $<1.2$ & 2.13 & $<0.2$ & $<1$ & 256 & $<0.02$ & 6.7 & 14 \\
\hline 425104114283702 & $<0.4$ & 2.76 & $<0.2$ & $<1$ & 157 & $<0.02$ & 8.0 & 168 \\
\hline 425037114294202 & $<0.4$ & 2.78 & $<0.2$ & $<1$ & 160 & $<0.02$ & 8.3 & 125 \\
\hline 424917114310601 & $<0.4$ & 2.71 & 0.2 & $<1$ & 196 & $<0.02$ & 9.6 & 342 \\
\hline 424835114545701 & 0.7 & 2.71 & 0.2 & $<1$ & 168 & $<0.02$ & 8.0 & 64 \\
\hline 424712114505901 & 2.2 & 1.22 & 0.2 & $<1$ & 542 & $<0.02$ & 6.8 & 105 \\
\hline 424732114482701 & $<0.4$ & 2.65 & $<0.2$ & $<1$ & 164 & $<0.02$ & 8.3 & 22 \\
\hline 424440114223701 & $<0.4$ & 2.18 & $<0.2$ & $<1$ & 206 & $<0.02$ & 6.8 & 56 \\
\hline 424441114224701 & $<0.4$ & 2.23 & $<0.2$ & $<1$ & 208 & $<0.02$ & 7.3 & 84 \\
\hline 424742114354901 & $<0.4$ & 2.64 & $<0.2$ & $<1$ & 200 & $<0.02$ & 8.9 & 15 \\
\hline 424540114335902 & 0.5 & 2.40 & $<0.2$ & $<1$ & 213 & $<0.02$ & 8.5 & 17 \\
\hline 424458114344001 & $<0.4$ & 2.33 & $<0.2$ & $<1$ & 210 & $<0.02$ & 7.3 & 22 \\
\hline 423908114314201 & $<0.4$ & 1.64 & 0.2 & $<1$ & 379 & $<0.02$ & 7.7 & 3 \\
\hline 423959114255301 & $<0.4$ & 1.63 & 0.2 & $<1$ & 378 & $<0.02$ & 6.4 & 69 \\
\hline 424621114435101 & $<0.4$ & 2.54 & $<0.2$ & $<1$ & 173 & $<0.02$ & 8.5 & 68 \\
\hline 424555114340601 & $<0.4$ & 2.23 & $<0.2$ & $<1$ & 192 & $<0.02$ & 8.1 & 12 \\
\hline 424103114300201 & $<0.4$ & 1.66 & 0.3 & $<1$ & 359 & $<0.02$ & 9.3 & 72 \\
\hline 424236114472202 & 0.6 & 2.27 & $<0.2$ & $<1$ & 197 & $<0.02$ & 8.2 & 5 \\
\hline 424209114391701 & $<0.4$ & 1.92 & $<0.2$ & $<1$ & 268 & $<0.02$ & 7.2 & 2 \\
\hline 424145114354201 & 2.0 & 1.61 & 0.3 & $<1$ & 345 & $<0.02$ & 7.3 & 673 \\
\hline 424251114285501 & $<0.4$ & 1.98 & $<0.2$ & $<1$ & 287 & $<0.02$ & 7.1 & 60 \\
\hline 424748114271801 & 0.9 & 1.70 & 0.3 & $<1$ & 326 & $<0.02$ & 16.4 & 207 \\
\hline 424545114380401 & 0.5 & 2.48 & $<0.2$ & $<1$ & 208 & $<0.02$ & 9.2 & 4 \\
\hline 424129114230201 & $<0.4$ & 2.25 & 0.2 & $<1$ & 382 & $<0.02$ & 6.7 & 147 \\
\hline 424040114324801 & $<0.4$ & 1.66 & 0.3 & $<1$ & 334 & $<0.02$ & 10.3 & 63 \\
\hline 424748114443401 & $<0.4$ & 2.08 & $<0.2$ & $<1$ & 225 & $<0.02$ & 7.8 & 25 \\
\hline 424403114483401 & $<0.4$ & 2.40 & $<0.2$ & $<1$ & 190 & $<0.02$ & 9.0 & 6 \\
\hline 424051114410501 & $<0.4$ & 1.90 & $<0.2$ & $<1$ & 292 & $<0.02$ & 7.4 & 11 \\
\hline
\end{tabular}


Appendix 1. Groundwater-quality data from 36 wells completed in the eastern Snake River Plain Aquifer, Jerome and Gooding Counties, south-central Idaho, 2017.-Continued

\begin{tabular}{|c|c|c|c|c|c|c|c|c|}
\hline $\begin{array}{c}\text { Site } \\
\text { identification } \\
\text { No. }\end{array}$ & $\begin{array}{l}\text { Antimony, } \\
\mu \mathrm{g} / \mathrm{L} \text { (water } \\
\text { filtered) }\end{array}$ & $\begin{array}{l}\text { Arsenic, } \\
\mu \mathrm{g} / \mathrm{L} \text { (water } \\
\text { filtered) }\end{array}$ & $\begin{array}{l}\text { Boron, } \\
\boldsymbol{\mu g} / \mathbf{L} \text { (water } \\
\text { filtered) }\end{array}$ & $\begin{array}{l}\text { Selenium, } \\
\mu \mathrm{g} / \mathrm{L} \text { (water } \\
\text { filtered) }\end{array}$ & $\begin{array}{c}\text { Organic } \\
\text { carbon, } \\
\text { mg/L (water } \\
\text { filtered) }\end{array}$ & $\begin{array}{l}\text { Uranium, } \\
\mu \mathrm{g} / \mathrm{L} \text { (water } \\
\text { filtered) }\end{array}$ & $\begin{array}{c}\text { Stable } \\
\text { isotope, delta } \\
{ }^{2} \mathrm{H} /{ }^{\prime} \mathbf{H}, \%\end{array}$ & $\begin{array}{c}\text { Stable } \\
\text { isotope, delta } \\
{ }^{18} 0 /{ }^{16} 0, \%\end{array}$ \\
\hline 424425114463401 & 0.09 & 2.47 & 48 & 0.65 & $<0.23$ & 1.71 & -135.6 & -17.85 \\
\hline 424618114471804 & $<0.03$ & 21.24 & 41 & $<0.05$ & $<0.23$ & $<0.01$ & -139.5 & -18.21 \\
\hline 424236114425301 & 0.11 & 2.40 & 55 & 0.65 & 3.42 & 1.82 & -135.7 & -17.77 \\
\hline 424033114481901 & 0.09 & 1.75 & 55 & 0.55 & 0.45 & 1.36 & -135.2 & -17.66 \\
\hline 424447114501201 & 0.10 & 2.30 & 45 & 0.69 & $<0.23$ & 1.79 & -136.1 & -17.74 \\
\hline 424909114510001 & 0.15 & 2.28 & 40 & 0.76 & $<0.23$ & 1.66 & -134.9 & -17.48 \\
\hline 424320114215401 & 0.09 & 2.24 & 54 & 0.57 & 0.27 & 1.65 & -135.3 & -17.62 \\
\hline 424327114380501 & 0.08 & 2.39 & 50 & 0.62 & 0.33 & 1.76 & -135.4 & -17.73 \\
\hline 424329114271801 & 0.08 & 2.15 & 60 & 0.80 & 0.48 & 2.08 & -133.7 & -17.59 \\
\hline 425104114283702 & 0.11 & 2.27 & 31 & 0.70 & 0.25 & 1.52 & -137.0 & -17.88 \\
\hline 425037114294202 & 0.09 & 2.27 & 32 & 0.72 & $<0.23$ & 1.56 & -136.7 & -17.90 \\
\hline 424917114310601 & 0.11 & 2.62 & 60 & 0.81 & 0.35 & 2.88 & -132.9 & -17.24 \\
\hline 424835114545701 & 0.08 & 2.65 & 35 & 0.70 & $<0.23$ & 1.69 & -136.1 & -17.70 \\
\hline 424712114505901 & 0.23 & 3.01 & 91 & 0.91 & 0.96 & 5.00 & -121.9 & -15.54 \\
\hline 424732114482701 & 0.11 & 2.18 & 34 & 0.73 & $<0.23$ & 1.75 & -136.2 & -17.76 \\
\hline 424440114223701 & 0.08 & 2.15 & 50 & 0.49 & 0.44 & 1.93 & -134.0 & -17.43 \\
\hline 424441114224701 & 0.09 & 2.40 & 48 & 0.50 & 0.28 & 1.94 & -133.6 & -17.44 \\
\hline 424742114354901 & 0.09 & 2.33 & 37 & 0.71 & 0.37 & 1.51 & -135.7 & -17.67 \\
\hline 424540114335902 & 0.08 & 2.26 & 43 & 0.61 & 0.27 & 1.52 & -135.0 & -17.80 \\
\hline 424458114344001 & 0.08 & 1.92 & 44 & 0.62 & 0.29 & 2.04 & -136.1 & -17.93 \\
\hline 423908114314201 & 0.09 & 2.72 & 80 & 0.91 & 1.97 & 2.73 & -127.3 & -16.57 \\
\hline 423959114255301 & 0.08 & 2.17 & 79 & 1.00 & 0.86 & 2.96 & -127.5 & -16.63 \\
\hline 424621114435101 & 0.08 & 2.28 & 36 & 0.69 & 0.26 & 1.83 & -135.9 & -17.82 \\
\hline 424555114340601 & 0.09 & 2.48 & 46 & 0.62 & 0.29 & 1.85 & -134.2 & -17.68 \\
\hline 424103114300201 & 0.09 & 2.97 & 83 & 0.94 & 0.92 & 3.55 & -127.5 & -16.63 \\
\hline 424236114472202 & 0.10 & 2.45 & 43 & 0.68 & 0.40 & 1.89 & -134.9 & -17.72 \\
\hline 424209114391701 & 0.08 & 2.30 & 53 & 0.80 & 0.50 & 2.48 & -132.3 & -17.51 \\
\hline 424145114354201 & 0.09 & 2.50 & 88 & 0.97 & 0.90 & 3.20 & -127.8 & -16.72 \\
\hline 424251114285501 & 0.08 & 2.17 & 68 & 0.89 & 0.79 & 2.31 & -132.8 & -17.34 \\
\hline 424748114271801 & 0.10 & 2.11 & 114 & 0.66 & 2.17 & 5.07 & -125.7 & -16.08 \\
\hline 424545114380401 & 0.08 & 2.31 & 41 & 0.61 & 0.45 & 1.50 & -135.7 & -17.81 \\
\hline 424129114230201 & 0.09 & 2.28 & 85 & 1.12 & 1.49 & 2.64 & -128.7 & -16.85 \\
\hline 424040114324801 & 0.11 & 3.59 & 73 & 0.83 & 1.01 & 3.75 & -127.5 & -16.43 \\
\hline 424748114443401 & 0.10 & 2.13 & 40 & 0.62 & 0.90 & 2.34 & -132.7 & -17.28 \\
\hline 424403114483401 & 0.09 & 2.57 & 43 & 0.68 & 0.52 & 1.88 & -135.2 & -17.87 \\
\hline 424051114410501 & 0.08 & 2.44 & 54 & 0.84 & 0.61 & 2.77 & -133.1 & -17.40 \\
\hline
\end{tabular}


Publishing support provided by the U.S. Geological Survey

Science Publishing Network, Tacoma Publishing Service Center

For more information concerning the research in this report, contact the Director, Idaho Water Science Center

U.S. Geological Survey

230 Collins Road

Boise, Idaho 83702

https://id.water.usgs.gov 
